\title{
Tribological Behavior of Borided AISI 316L Steel with Reduced Friction Coefficient and Enhanced Wear Resistance
}

\author{
Enrique Hernández-Sánchez ${ }^{1, *}$, Julio C. Velázquez ${ }^{2}$, José. L. Castrejón-Flores ${ }^{1}$, Alexis Chino-Ulloa ${ }^{1}$, \\ Itzel P. Torres Avila ${ }^{1}$, Rafael Carrera-Espinoza ${ }^{3}$, Jorge A. Yescas-Hernández ${ }^{3}$ and Carlos Orozco-Alvarez ${ }^{1}$ \\ ${ }^{1}$ Departamento de bioingeniería, Instituto Politécnico Nacional, UPIBI, Avenida Acueducto s/n Barrio La Laguna Ticomán, \\ 07340, México City, México \\ ${ }^{2}$ Departamento de Ingeniería Química Industrial, ESIQIE, Instituto Politécnico Nacional, \\ UPALM Edif. 7, Zacatenco, México City 07738, México \\ ${ }^{3}$ Departamento de ingeniería Industrial y Mecánica, Universidad de las Américas Puebla, Santa Catarina Mártir $s / n$, \\ 72810, San Andrés Cholula, Puebla, México
}

\begin{abstract}
This study evaluates the tribological behavior of borided AISI 316L steel. The treatment time was set to 2, 4, and $6 \mathrm{~h}$ at temperatures of 850,900 , and $950^{\circ} \mathrm{C}$ for each time duration. The morphology and microstructure of the boride layers were analyzed by scanning electron microscopy (SEM) and X ray diffraction (XRD), respectively. The mechanical properties were evaluated by an instrumented nanoindentation test. The tribological behaviors of the layers were evaluated using a sand/rubber apparatus following the ASTM G-65 standard. The friction coefficient of the boride layers was estimated by means of the tribological pin-on-disk test. The results show that the experimental parameters had a clear influence on the thickness of the boride layers and on their mechanical properties. The volume loss was established in the range of $0.0741 \pm 0.011 \mu \mathrm{g}$ to $1.6148 \pm 0.150 \mu \mathrm{g}$. Wear mechanisms such as adhesion and micro-fatigue were mainly observed in the samples exposed for $6 \mathrm{~h}$ at $950^{\circ} \mathrm{C}$. Finally, the friction coefficient was reduced from 0.7 for the as-received material down to 0.29 for the borided samples. The wear mechanisms were discussed as a function of the scanning electron microscopy observations. It is possible to conclude that single-phase layers of $\mathrm{Fe}_{2} \mathrm{~B}$ are more apt to face wear than the $\mathrm{FeB} / \mathrm{Fe}_{2} \mathrm{~B}$ biphasic layers. [doi:10.2320/matertrans.M2018282]
\end{abstract}

(Received August 28, 2018; Accepted October 31, 2018; Published November 30, 2018)

Keywords: boriding, tribological behavior, wear, coefficient of friction

\section{Introduction}

AISI 316L stainless steel is a well-known low-cost steel alloy that is suitable for medical applications because of its high resistance to corrosion and low response to human fluids. However, the high content of $\mathrm{Ni}(9 \%)$ in this steel alloy gives it an austenitic structure at room temperature. This, along with its low carbon content $(0.03 \%)$, makes the alloy difficult to harden by conventional methods. Consequently, its hardness (200 HV) and wear resistance remain low, limiting its use in orthopedic medicine to the manufacture of permanent prostheses. ${ }^{1)}$

It has been shown that one of the main causes of joint prosthesis replacement surgery is aseptic loosening, which is associated with tissue reaction to the wear particles from the implant material that are produced by friction between the contacting surfaces. ${ }^{2)}$ For this reason, several researchers have tried to develop different surface modification techniques aimed at reducing the friction coefficient of the materials and, thus, reducing wear and the shedding of particles into living tissue. ${ }^{3)}$

For example, boriding is a thermochemical process in which atoms of boron diffuse into a metallic matrix that enhances their mechanical and chemical surface properties. The process takes place in solid, liquid, or gaseous media. The most commonly used method is pack boriding (solid media) because it is inexpensive and easy to perform. $\left.{ }^{4,5}\right)$ During pack boriding, boron is generally provided from boron carbide $\left(\mathrm{B}_{4} \mathrm{C}\right)$ or amorphous boron, an activator to deposit atomic boron on the substrate surface, and a diluent.

*Corresponding author, E-mail: enriquehs266@yahoo.com.mx
The process involves embedding the samples in the powder mixture and sealing them in a container. ${ }^{6)}$ This process is expected to produce iron borides with single-phase $\mathrm{Fe}_{2} \mathrm{~B}$ (containing approximately 8.83 mass $\%$ B) or double-phase $\mathrm{FeB} / \mathrm{Fe}_{2} \mathrm{~B}$ (with $\mathrm{FeB}$ phase containing approximately 16.23 mass \% B). ${ }^{7)}$ A variety of features such as the chemical composition of the substrate, the boron potential supplied during the process, the temperature, and the treatment time determine the resulting single- or double-phase layer and thickness. ${ }^{8)}$

This work aims to study the tribological behaviors of AISI 316L borided under different conditions. The main reason for selecting this hardening process was because it has been proven to enhance the surface properties of treated materials, mainly the hardness, coefficient of friction (COF), wear resistance, and corrosion resistance ${ }^{6)}$ of other alloys. Therefore, the results of this study will provide information about the best treatment conditions as a function of the wear conditions of the work elements.

\section{Experimental Details}

\subsection{Boriding process}

Cylindrical samples of AISI 316L SS (0.03 mass\% C, 1.0 mass $\% \mathrm{Si}, 2.0$ mass $\% \mathrm{Mn}, 0.045$ mass $\% \mathrm{P} \max , 0.03$ mass $\% \mathrm{~S}, 16-18$ mass $\% \mathrm{Cr}, 10-14$ mass $\% \mathrm{Ni}$ and 2-3 mass $\%$ Mo) of $50.8 \mathrm{~mm}$ diameter and $10 \mathrm{~mm}$ height were sequentially polished with $80-1500 \mathrm{SiC}$ paper. Then, the samples were cleaned by sonication in ethanol for $5 \mathrm{~min}$, rinsed with distilled water, dried in hot air, and finally embedded in a cylindrical case (AISI 304) containing a $\mathrm{B}_{4} \mathrm{C}$ fresh powder mixture with a particle size of $50 \mu \mathrm{m}$ in open 
Table 1 Numerical order of the samples as a function of the treatment conditions.

\begin{tabular}{ccc}
\hline & \multicolumn{2}{c}{ Treatment conditions } \\
\hline $\begin{array}{c}\text { Sample } \\
\text { number }\end{array}$ & $\begin{array}{c}\text { Time } \\
(t / \mathrm{h})\end{array}$ & $\begin{array}{r}\text { Temperature } \\
\left(\mathrm{T} /{ }^{\circ} \mathrm{C}\right)\end{array}$ \\
\hline 0 & Non-borided sample \\
\hline 1 & 2 & \\
2 & 4 & 850 \\
3 & 6 & \\
\hline 4 & 2 & \\
5 & 4 & \\
6 & 6 & \\
\hline 7 & 2 & \\
8 & 4 & 950 \\
9 & 6 & \\
\hline
\end{tabular}

air. Samples were covered with $15 \mathrm{~mm}$ of powder on each side to prevent oxidation.

Boriding was carried out at temperatures of 850,900 , and $950^{\circ} \mathrm{C}$ for periods of 2,4 , and $6 \mathrm{~h}$ at each temperature in a conventional furnace. After boriding, samples were allowed to cool outside the furnace at room temperature and were cleaned in an ultrasonic bath with ethanol/deionized water $(50 / 50)$. Samples were numbered in sequential order as indicated in Table 1. To ensure the reproducibility of the results, three samples were treated for each treatment condition according to the ASTM G-65 standard.

\subsection{Characterization}

Layer thickness was estimated using an optical microscope by taking at least 50 measurements from different sections along the sample length. The morphologies of the layers were examined by scanning electron microscopy (SEM). The resulting phases were determined by $\mathrm{X}$ ray diffraction (XRD), with a diffractometer equipped with $\mathrm{Cu}-\mathrm{K} \alpha$ radiation and a wavelength of $1.5418 \AA$. Harnesses of the boride layers were evaluated by instrumented indentation on a nano hardness tester (TTX-NHT, CSM Instruments) using a Berkovich indenter, according to the methodology established by Oliver and Pharr. ${ }^{9)}$

\subsection{Wear test}

The weight of the samples was measured both before and after the wear tests using an analytical balance $(0.0001 \mathrm{~g}$ accuracy). Following the ASTM-G65 standard for hard coatings and thin films (Procedure C), ${ }^{10}$ the test parameters were: applied load $=130 \mathrm{~N} ; \quad$ speed $=100 \mathrm{rpm} ; \quad$ sliding distance $=71.8 \mathrm{~m}$, and sand flow $=300-400 \mathrm{~g} / \mathrm{min}$. The samples were tested for periods of $30,60,90,120$, and $150 \mathrm{~s}(35.9,71.8,107.7,143.6$, and $179.5 \mathrm{~m}$ sliding distance) to evaluate the tribological behaviors of the boride layers as a function of the treatment conditions and the sliding distance.

The wear mechanisms on the wear tracks were determined by SEM, and the wear resistance was evaluated by calculating loss of volume, as follows: ${ }^{10)}$

$$
V_{l}=\left(m_{l} / \rho\right) \times 1000
$$

The wear rate of the borided samples during wear tests was evaluated by Archard's equation. ${ }^{11)}$

$$
W=V_{l} / P d
$$

where $V_{l}$ is the volume loss during the test $\left[\mathrm{mm}^{3}\right], m_{l}$ is the mass lost [g], $\rho$ is the density of the test material $\left[\mathrm{g} \mathrm{cm}^{-3}\right], W$ is the wear rate $\left[\mathrm{mm}^{3} \mathrm{~N}^{-1} \mathrm{~m}^{-1}\right], P$ is the applied load $[\mathrm{N}]$, and $d$ is the sliding distance $[\mathrm{m}]$.

The density of the involved materials $(\rho)$, was calculated according to the Equation proposed by Gloker, ${ }^{6}$ as follows:

$$
\rho=N A m_{H} / V_{c}
$$

where $\rho$ is the density of the boride layers $\left[\mathrm{g} \mathrm{cm}^{-3}\right], N$ is the coordination number for each crystalline cell, $A$ is the average of the atomic weight of the corresponding elements in the boride phases $\mathrm{FeB}$ and/or $\mathrm{Fe}_{2} \mathrm{~B}$, and $m_{H}$ is the absolute unit of mass of atomic weight $\left[1.66 \times 10^{-24} \mathrm{~g}\right]$. The achieved density values of the boride phases were: 6.75 and $7.43 \mathrm{~g} \mathrm{~cm}^{-3}$ for $\mathrm{FeB}$ and $\mathrm{Fe}_{2} \mathrm{~B}$, respectively. The density of the AISI $316 \mathrm{~L}$ SS was obtained from the literature $\left(7.9 \mathrm{~g} \mathrm{~cm}^{-3}\right)$.

\section{$2.4 \mathrm{COF}$}

The COF of the boride layers was evaluated with the pinon-disk technique using a ball-on-disk tribometer. A tungsten carbide (WC) ball was secured to a stationary holder, and the AISI 316L borided samples were attached to a horizontal chuck driven by a variable-speed electric motor. All tests were carried out at a controlled temperature of $19^{\circ} \mathrm{C}$ and $40 \%$ relative humidity using a constant rotational speed of $10 \mathrm{rpm}$, a constant sliding speed of $0.05 \mathrm{~m} \mathrm{~s}^{-1}$, a sliding distance of $200 \mathrm{~m}$, and a $5 \mathrm{~N}$ normal load applied to the WC ball.

\section{Results and Discussions}

\subsection{Characterization}

Figure 1 show cross-sectional micrographs of the boride layers obtained on the borided AISI 316L SS samples for the different treatment conditions (samples 1-9). Compared with borided low-carbon steels, where the front of growth is highly jagged (Fig. 1(j)), the morphologies of the obtained layers were flat, which is expected when SS is exposed to boriding. ${ }^{6,12)}$

The flat morphologies of the boride layers are due to the high content of alloying elements in the substrate, especially $\mathrm{Cr}$ and $\mathrm{Ni}$, which react with boron to form compounds such as $\mathrm{CrB}, \mathrm{Cr}_{2} \mathrm{~B}, \mathrm{NiB}$, and $\mathrm{Ni}_{3} \mathrm{~B}$. These compounds tend to act as a diffusion barrier, consuming much of the available energy for the growth of the layers. Consequently, the layer thickness is also lower than with low-carbon steels under the same treatment conditions (approximately 30 to $200 \mu \mathrm{m}$ ). ${ }^{6,13)}$

Three different zones can be inferred by observing the SEM micrographs of the cross-sections of the borided samples and the X-ray diffractograms (Figs. 1 and 2). The outermost zone is the boride layer, which is mainly composed of a double-phase $\mathrm{FeB} / \mathrm{Fe}_{2} \mathrm{~B}$ type layer. Compounds such as $\mathrm{CrB}$ and $\mathrm{Ni}_{3} \mathrm{~B}$ were also present to a lesser extent. A second zone, called a diffusion zone, lies below the boride layers. The third zone is the substrate, which is not affected by boron diffusion. The composition, morphology, and thickness of 

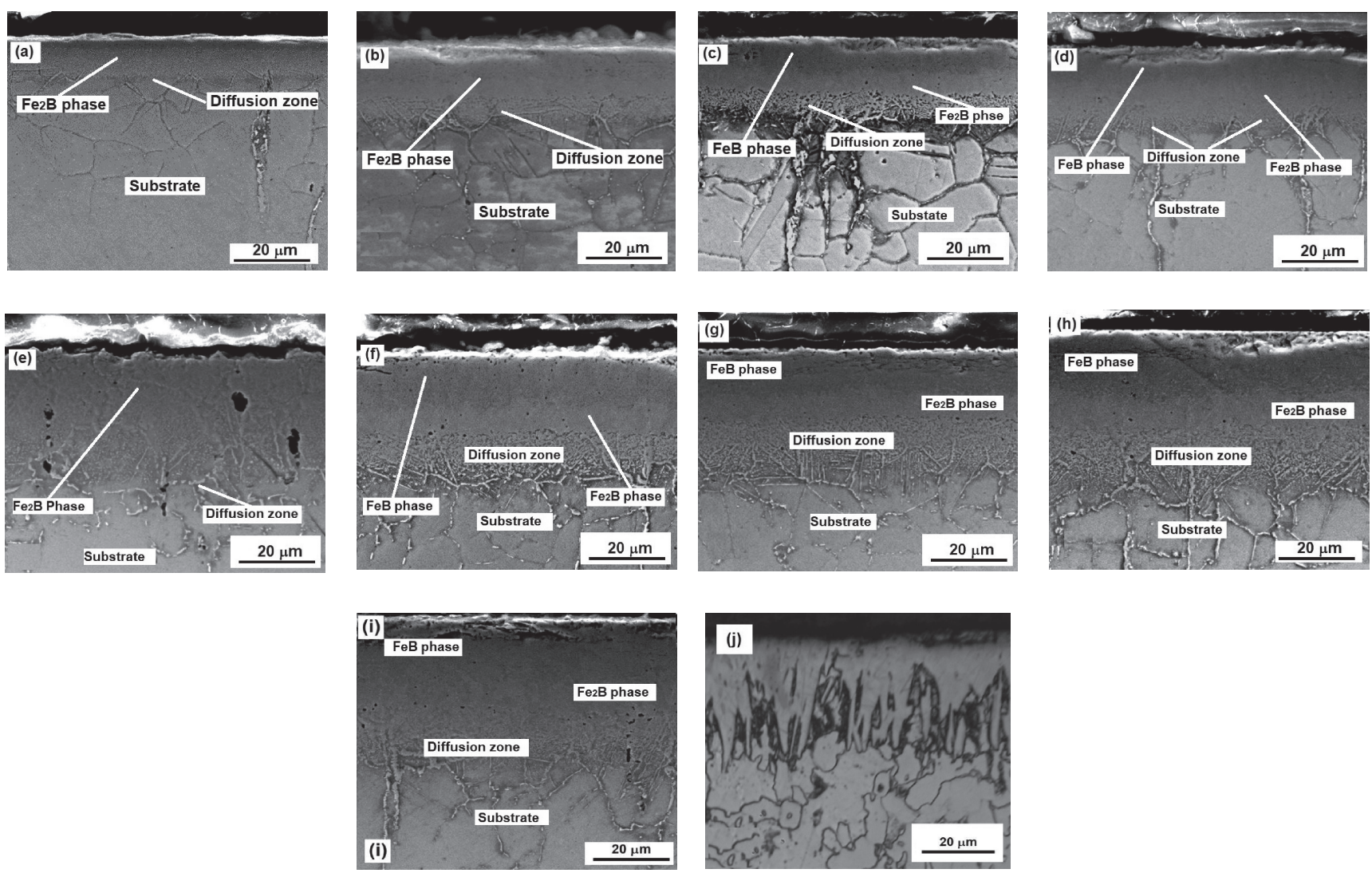

Fig. 1 SEM image of (a-i) cross-sections of the AISI 316L SS exposed to boriding (micrographs a-i represent the treatment conditions) according to Table 1, and (j) sample of AISI 1018 exposed to boriding for $2 \mathrm{~h}$ at $900^{\circ} \mathrm{C}$.

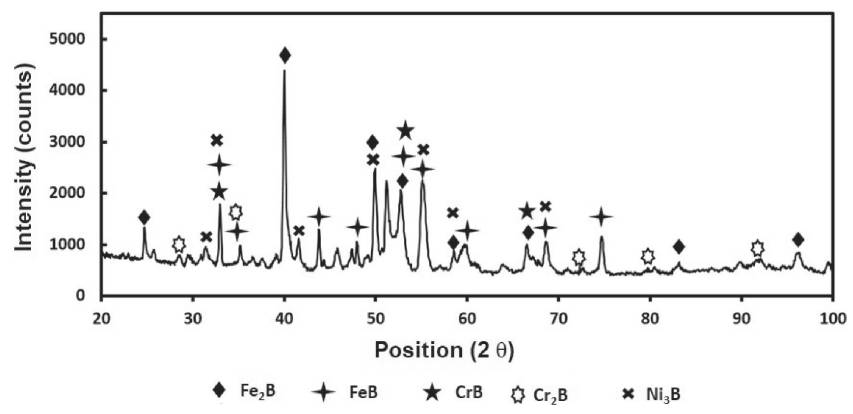

Fig. 2 XRD pattern of the surface of the sample exposed to $950^{\circ} \mathrm{C}$ for $6 \mathrm{~h}$.

the boride layers (see Fig. 1) were similar to those reported in the literature for AISI 316 SS exposed to the pack boriding method. ${ }^{13,14)}$

Figure 2 shows an XRD pattern corresponding to sample 9. The patterns were indexed with data cards 00036-1332, 00-032-0463, 00-032-0277, 98-061-3465, and 98-002-4306, which represent the XRD patterns of $\mathrm{Fe}_{2} \mathrm{~B}$, $\mathrm{FeB}, \mathrm{CrB}, \mathrm{Cr}_{2} \mathrm{~B}$, and $\mathrm{Ni}_{3} \mathrm{~B}$ phases, respectively.

According to the XRD pattern, the main phases are FeB and $\mathrm{Fe}_{2} \mathrm{~B}$, which is as expected when $\mathrm{SS}$ is exposed to boriding. On the other hand, the affinity of boron for $\mathrm{Ni}$ is less than for iron or $\mathrm{Cr}$, so $\mathrm{Ni}$ also diffuses from the steel, but in a lower amount and is located beneath the layer. ${ }^{13,15)}$ This behavior may be the cause of the low thickness of the boride layers in AISI $316 \mathrm{~L} \mathrm{SS}$, because the $\mathrm{Ni}$ and $\mathrm{Cr}$ compounds beneath the layers could act as a diffusion barrier. This agrees well with the literature about borided austenitic steels reporting the presence of $\mathrm{FeB}$ and $\mathrm{Fe}_{2} \mathrm{~B}$ phases after boriding. ${ }^{13-19)}$ Similarly, chromium and nickel borides appeared in the diffusion-boride layer.

The layer thickness ranged from $10.21 \pm 0.71 \mu \mathrm{m}$ for sample 1 up to $51.25 \pm 6.71 \mu \mathrm{m}$ for sample 9, where the growth of the layer's thickness obeys a parabolic law as follows: ${ }^{14,20-22)}$

$$
x^{2}=K t
$$

where $x$ is the layer thickness [m], $K$ is the parabolic growth rate $\left[\mathrm{m}^{2} \mathrm{~s}^{-1}\right]$, and $t$ is the treatment time $[\mathrm{s}]$.

The layer thickness showed a clear dependence on the treatment conditions, as shown in Fig. 3.

Both temperature and treatment time have a great influence on layer thickness, however, temperature appears to have more impact on layer growth compared with treatment time (see Fig. 3). The explanation for this behavior is that, as boriding is a thermally activated process, temperature has a high influence on the layer's growth. ${ }^{\text {) }}$

C.M. Brackman et $a l .{ }^{23)}$ established the contribution of the period of time at the beginning of the boriding process in which the layers start to grow, referred to as incubation time $\left(t_{0}\right)$. According to the authors, the incubation time can be estimated by the projection of a straight line resulting from the graph "boride layer thickness versus exposure time" to the $x$-axis. Figure 3(b) shows that in this study, higher temperatures resulted in a shorter $t_{0}$ and, consequently, higher layer thickness.

Figure 4 shows the hardness profiles of the boride layers for the different treatment conditions. 

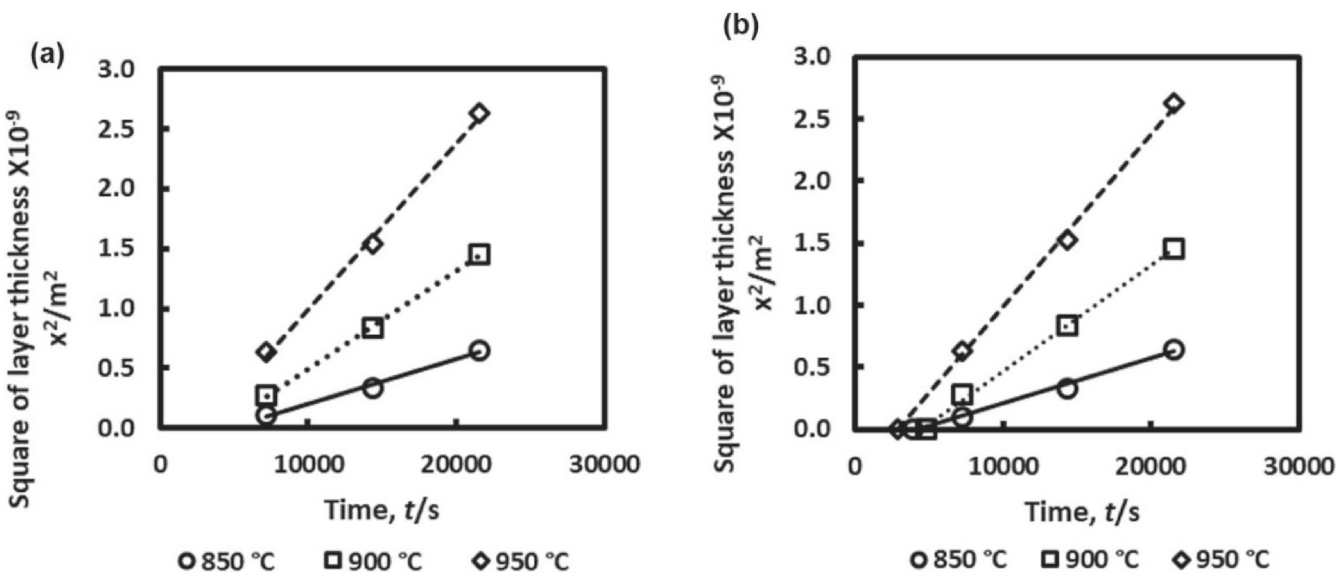

Fig. 3 Square of layer thickness as a function of the treatment conditions for (a) the treatment time, and (b) including the incubation time.
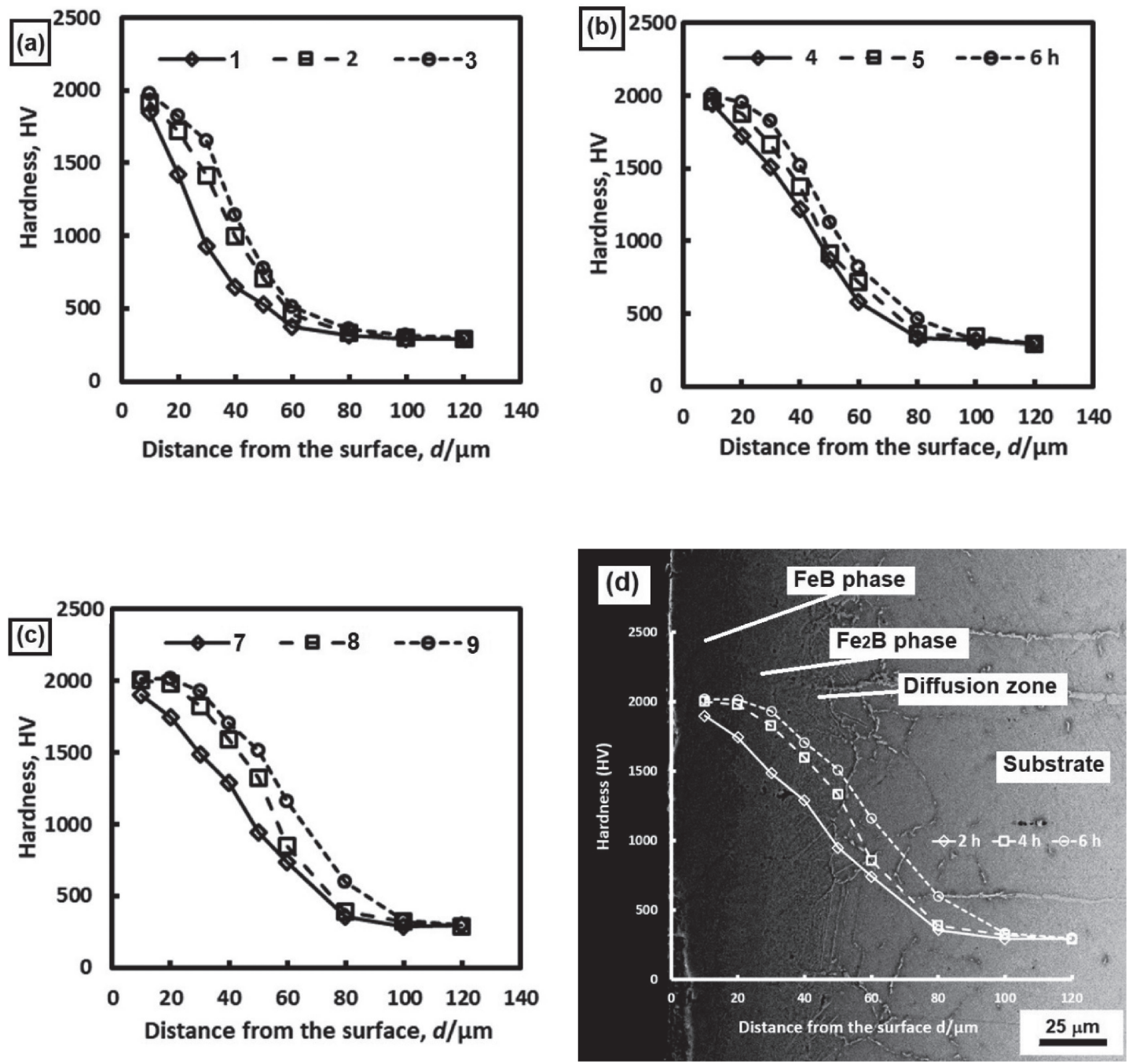

Fig. 4 Nano hardness profiles of the samples exposed to (a) $850^{\circ} \mathrm{C}$ (b) $900^{\circ} \mathrm{C}$, and (c) $950^{\circ} \mathrm{C}$. (d) Different phases of the boride layer.

The highest hardness values $(2017 \pm 179.25 \mathrm{HV})$ were achieved in sample 9 (Fig. 4(d)). According to Fig. 4, the hardness of the boride layers is highly dependent on the treatment conditions. These results can be attributed to boron enrichment of the layers as the process evolves, so that the layers become more compact, and the compounds formed tend to become saturated with boron until equilibrium is reached. In addition, the hardness values reflect the boron concentration on the layers, because the highest hardness was achieved with the highest layer thickness. Campos et al. ${ }^{13)}$ have established that boride layers on AISI $316 \mathrm{SS}$ are mainly compounds of $\mathrm{FeB} / \mathrm{Fe}_{2} \mathrm{~B}$ phases. $\mathrm{Fe}_{2} \mathrm{~B}$ phase is the first to form, and if the process continues, $\mathrm{FeB}$ is formed, so the hardness is higher at the surface of the sample. 

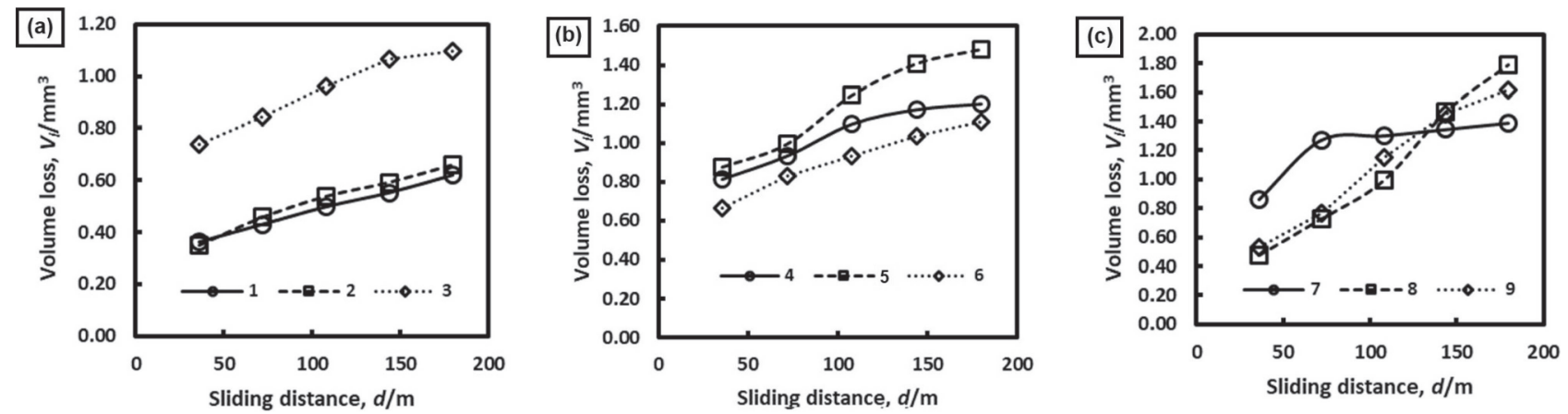

Fig. 5 Volume loss as a function of the sliding distance for treatment time of 2,4 , and $6 \mathrm{~h}$ at an exposure temperature of (a) $850^{\circ} \mathrm{C}$ (b) $900^{\circ} \mathrm{C}$, and (c) $950^{\circ} \mathrm{C}$.

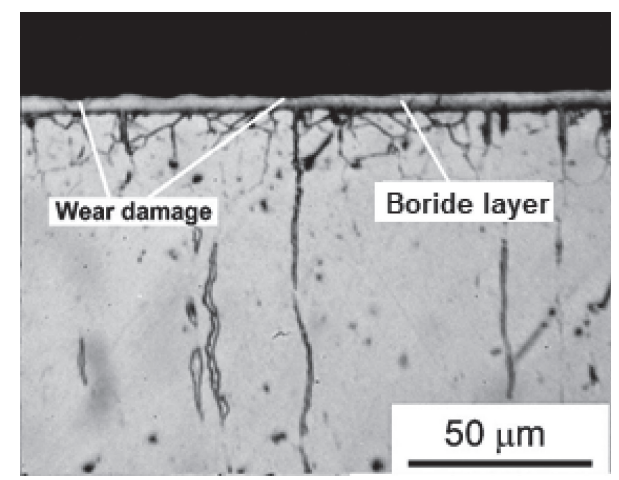

Fig. 6 Optical view of cross-section of sample number $1\left(850^{\circ} \mathrm{C}\right.$ and $2 \mathrm{~h}$ of treatment) after wear tests.

\subsection{Wear tests}

The values of volume loss, presented in Fig. 5 (calculated using eq. (1)), show a marked dependence on temperature. Thus, the higher the temperature, the more brittle the layer is.

Figure 6 shows that the boride layer was not totally eliminated during the wear tests, even in sample 1 (sample with the smallest layer thickness). Also, the energy dispersive spectroscopy test (EDS) of sample 1 corroborates the presence of boron at the surface (Fig. 7). Conversely, because the boride layers were not totally eliminated during the wear tests, the density of $\mathrm{FeB}$ and $\mathrm{Fe}_{2} \mathrm{~B}\left(6.75 \mathrm{~g} \mathrm{~cm}^{-3}\right.$ and 7.45 $\mathrm{g} \mathrm{cm}^{-3}$, respectively) were used for the calculation of volume loss. ${ }^{6,11)}$

The images in Fig. 7 show the presence of boron and $\mathrm{Fe}$ homogeneously distributed along the wear track, which indicates the prevalence of the boride layer after the wear tests. Figure 7 also shows $\mathrm{Cr}$ and Mo which are alloy elements of the AISI 316L SS. Additionally, according to the results presented in Fig. 5(a)-(c), it is possible to make the following observations:

i) The volume loss of samples 1, 2, and 3 exhibited a linear relationship with the sliding distance, and sample 3 exhibited higher volume loss than samples 1 and 2 . The reason for this behavior may be that the boride layer starts to grow as the diffusion process evolves. ${ }^{24)}$ It can be assumed that the only phase formed under the 2 and $4 \mathrm{~h}$ treatment conditions is $\mathrm{Fe}_{2} \mathrm{~B}$ (see Fig. 1) because the required time for this process depends mainly on the temperature, ${ }^{6)}$ which is relatively low $\left(850^{\circ} \mathrm{C}\right)$ in this stage. In addition, in previous work ${ }^{25)}$ we reported that $\mathrm{Fe}_{2} \mathrm{~B}$ phase is more elastic than $\mathrm{FeB}$, so an $\mathrm{Fe}_{2} \mathrm{~B}$
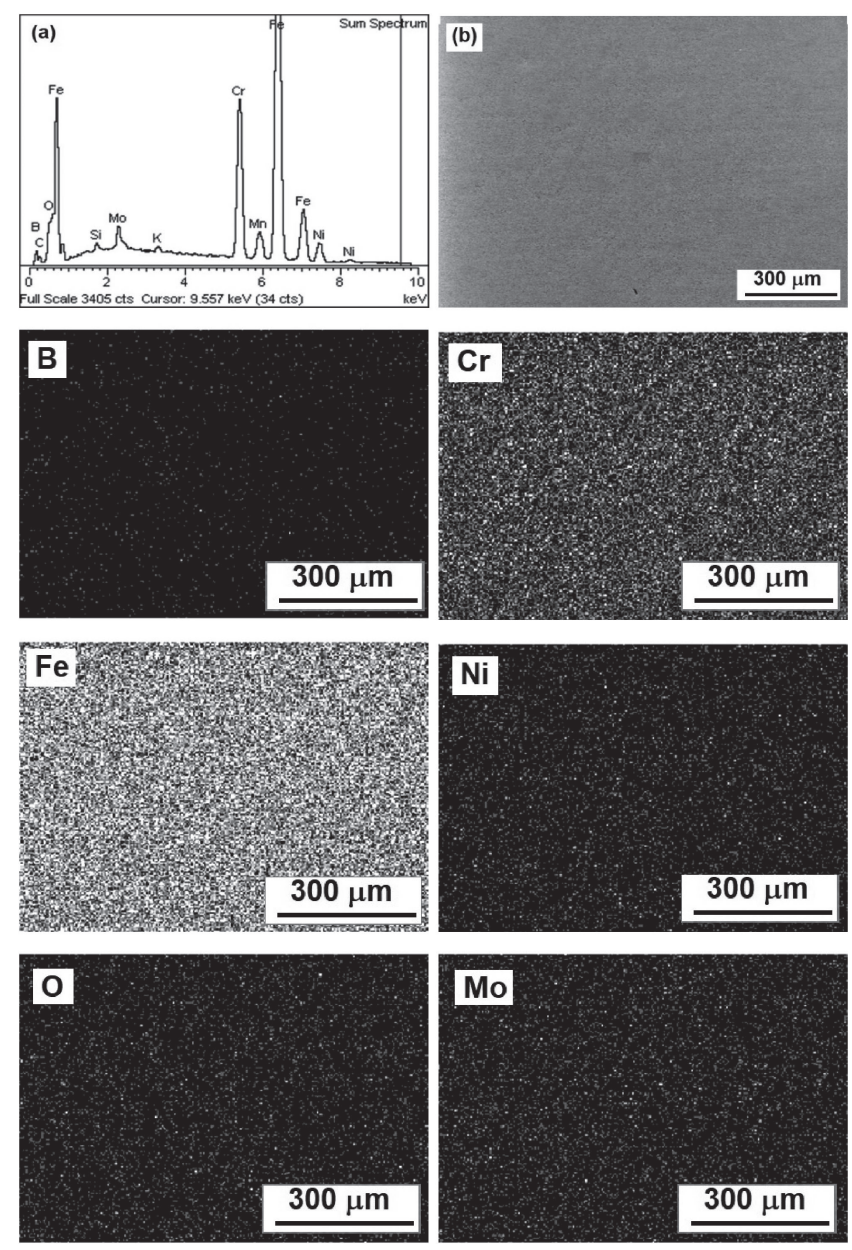

Fig. 7 EDS results obtained from analyzing worn track of sample number 1 .

single-phase layer is expected to be more resistant to abrasive wear, as can be seen in Fig. 5(a).

ii) The volume loss of samples 4, 5, and 6 exhibited linear behavior, where sample 4 presented the smallest value even when compared with all the samples exposed to the $850^{\circ} \mathrm{C}$ condition. This behavior can be attributed to the growth of the FeB layer (about $38 \mu \mathrm{m}$ ) due to the increase in temperature of the treatment. According to previous research, ${ }^{26,27)}$ layer thicknesses over $15-20 \mu \mathrm{m}$ are more resistant to abrasive and adhesive wear, which are the main wear mechanisms observed during the tests. In addition, from 
(a)

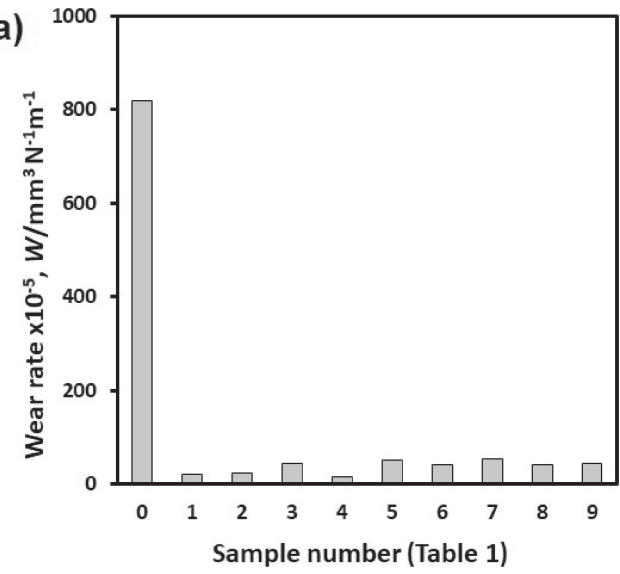

(b)

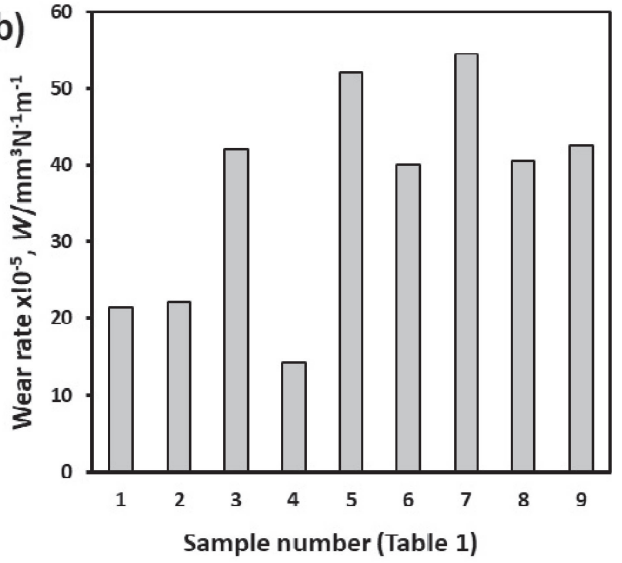

Fig. 8 Wear rate as a function of the treatment conditions according to Table 1 (a) considering the non-borided sample, and (b) only the treated samples.

the cross-section of the sample exposed to $900^{\circ} \mathrm{C}$ for $6 \mathrm{~h}$ (Fig. 1(e)), it can be observed that the $\mathrm{FeB}$ phase was practically eliminated during the wear tests. Therefore, a thickness above $15 \mu \mathrm{m}$ and the lack of an FeB layer may explain the high wear rate (shown in Fig. 8) due to the high brittleness of $\mathrm{FeB}$ phase, which increases as the $\mathrm{FeB}$ thickness increases because of the treatment conditions. The brittleness parameter compares the deformation process to the fracture process; higher values of brittleness denote that the material is more susceptible to fracture as a result of its high hardness and stiffness. ${ }^{28)}$

iii) Finally, samples prepared at $950^{\circ} \mathrm{C}$ exhibited higher volume loss compared with the other temperature conditions. Although increasing hardness and layer thickness suggested that the boride layers should be less susceptible to wear, the opposite happened. This apparently contradictory behavior can be explained by the lower brittleness of the layers when their hardness and thickness are lower. ${ }^{28-30)}$ Therefore, as the hardness of the samples exposed to $850^{\circ} \mathrm{C}$ and $900^{\circ} \mathrm{C}$ are lower due to the low formation of $\mathrm{FeB}$ phase, the boride layers achieved under those conditions are also less susceptible to wear than those exposed to $950^{\circ} \mathrm{C}$.

M. Tabur et al. ${ }^{31)}$ agreed with this assumption in their investigation on the abrasive wear behavior of boronized AISI 8620 steel. They found that samples exposed to higher temperatures presented higher wear than those exposed to lower temperatures, mainly because of the formation of $\mathrm{FeB}$ phase.

Figure 8 shows the wear rate of the borided and nonborided samples under different treatment conditions (see Table 1).

Compared with non-borided steel (Fig. 8(a)), the wear rate was diminished in all samples. Sample number 4 exhibited the lowest wear rate even when its hardness and layer thickness were not the highest. In fact, sample 1 presented the lowest hardness and layer thickness values of all the samples. This wear rate behavior is similar to that of volume loss. In addition, it can be observed that the highest wear rate occurs at the beginning of the tests related to the different temperature conditions (see Fig. 5). This behavior could be due to the presence of $\mathrm{FeB}$ phase at the surface of the boride layers; thus, when FeB phase has been eliminated, the wear rate exhibits linear behavior. Moreover, sample 5 (Fig. 5(b)) exhibited linear behavior from the beginning of the tests. This can be explained by the fact that under such treatment conditions, the thickness of both phases (FeB/ $\mathrm{Fe}_{2} \mathrm{~B}$ ) is practically the same, so the hardness gradient from the surface to the substrate decreases gradually, making the layer more resistant to wear conditions. Martini et al. ${ }^{32)}$ reported that the wear rates of the boride layers were considerably lower for inner regions that, on the basis of their metallographic observations, were found to be constituted of $\mathrm{FeB}$ and, to a less extent, by $\mathrm{Fe}_{2} \mathrm{~B}$. They also reported that further inward through the coating, the wear rate increased for regions around the $\mathrm{FeB}-\mathrm{Fe}_{2} \mathrm{~B}$ interface and reached a minimum in the regions constituted of highly ordered $\mathrm{Fe}_{2} \mathrm{~B}$ crystals. Furthermore, the wear rate is very high under both abrasive and adhesive conditions because of a brittle outer layer with irregular crystal structure over the boride coating.

Figure 9 shows the wear mechanisms present at the wear scars of the borided samples, which are the main precursors of wear.

Wear mechanisms such as delamination, plastic deformation, micro-cracking, micro-plowing, micro-fatigue, and micro-cutting can be observed in the images of the wear scars (see Fig. 9). These wear mechanisms commonly happen when hard layers are exposed to wear, due to the interaction between the surface of the sample and an abrasive agent. According to Fig. 9, the main failure mechanism seems to be the creation of micro-cracks due to high contact pressure during the wear tests. In that sense, the layer with the highest hardness values are also the most likely to suffer fracture because of the high hardness gradient between the layer and the substrate, and their subsequent brittleness. ${ }^{31)}$ This behavior agrees well with the results of volume loss, where volume loss was directly proportional to the hardness of the layers.

These results suggest that a biphasic layer such as $\mathrm{FeB} /$ $\mathrm{Fe}_{2} \mathrm{~B}$ is more susceptible to wear than a $\mathrm{Fe}_{2} \mathrm{~B}$ monophasic layer. This should be considered in generating single-layer $\mathrm{Fe}_{2} \mathrm{~B}$ or in eliminating the $\mathrm{FeB}$ layer by a secondary process, to improve the wear resistance by improving the fracture toughness of the boride layers. ${ }^{33)}$ 

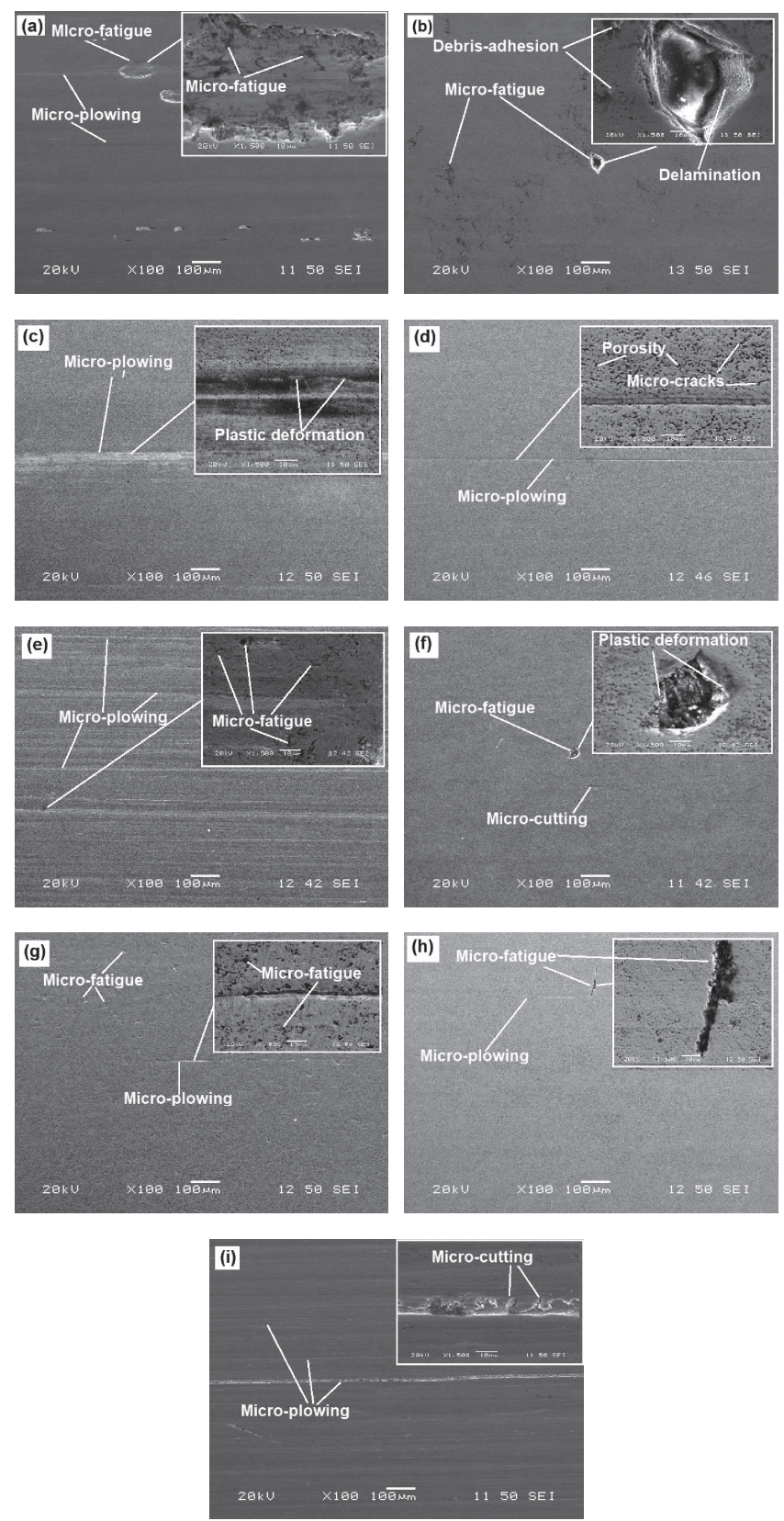

Fig. 9 SEM images of wear scars of samples 1-9 (samples a-i represent samples 1-9 according to Table 1) after $179.5 \mathrm{~m}$ of sliding distance.

\subsection{COF}

Figure 10 describes the behavior of the COF of the boride layers as a function of the treatment conditions (see Table 1).

Compared with the non-borided sample, where the COF is 0.8 , the borided samples showed a reduction in COF under all treatment conditions. Furthermore, the COF was inversely proportional to the layer thickness because the lowest COF value was achieved with the thickest layer (sample 9), as Table 2 shows.

The reason for this behavior is that when temperature and treatment time increases, layer thickness also increases, and consequently, FeB phase increases. This sequence of events combined with the spontaneous increase in temperature due to the pin-on-disk tests seems to promote the formation of a spontaneous thin film of boric acid $\left(\mathrm{H}_{3} \mathrm{BO}_{3}\right)$ at the surface of

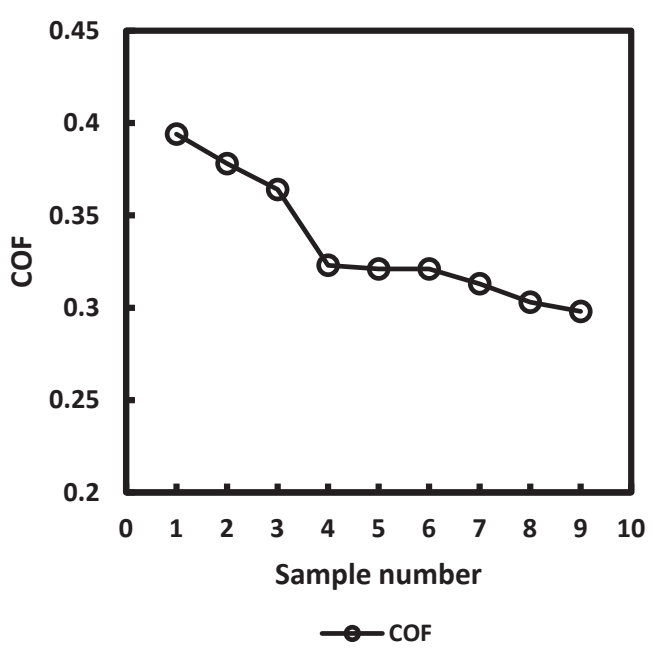

Fig. 10 Behavior of COF as a function of the treatment conditions.

Table 2 Relation between the layer's thickness and the coefficient of friction $(\mathrm{COF})$.

\begin{tabular}{ccc}
\hline $\begin{array}{c}\text { Sample } \\
\text { number }\end{array}$ & $\begin{array}{c}\text { Layer thickness } \\
(x / \mu \mathrm{m})\end{array}$ & COF \\
\hline 1 & $10.21 \pm 2.19$ & $0.394 \pm 0.111$ \\
2 & $18.34 \pm 2.43$ & $0.378 \pm 0.146$ \\
3 & $25.45 \pm 3.12$ & $0.364 \pm 0.125$ \\
4 & $16.68 \pm 2.82$ & $0.323 \pm 0.132$ \\
5 & $28.98 \pm 3.01$ & $0.321 \pm 0.154$ \\
6 & $38.17 \pm 4.21$ & $0.321 \pm 0.097$ \\
7 & $25.14 \pm 3.15$ & $0.313 \pm 0.079$ \\
8 & $39.16 \pm 3.42$ & $0.303 \pm 0.069$ \\
9 & $51.25 \pm 4.87$ & $0.298 \pm 0.055$ \\
\hline
\end{tabular}

the borided samples, which acts as a solid lubricant, as shown in Fig. 11. ${ }^{34-36)}$

By examination of Fig. 11, it can be understood why the COF values diminish. The XRD analysis was applied to sample 5 after the pin-on-disk test, and it revealed the presence of $\mathrm{H}_{3} \mathrm{BO}_{3}$ at the surface of the sample. The formation of $\mathrm{FeB}$ phase most likely enhanced the growth of the $\mathrm{H}_{3} \mathrm{BO}_{3}$ film due to its high boron content. The formation of $\mathrm{H}_{3} \mathrm{BO}_{3}$ film can be explained as follows: When a boronrich surface is heated the boron reacts with the oxygen and undergoes oxidation to form a boron oxide $\left(\mathrm{B}_{2} \mathrm{O}_{3}\right)$ film on the exposed surface. ${ }^{34)}$ During cooling, the $\mathrm{B}_{2} \mathrm{O}_{3}$ film undergoes a secondary chemical reaction upon contact with environmental moisture to form a thin $\mathrm{H}_{3} \mathrm{BO}_{3}$ film, which because of its crystalline structure, is considered a solid lubricant. In addition, when two surfaces slide against one another, most of the generated energy is dissipated as heat. Moreover, in most situations of sliding wear, the real contact between the involved surfaces is always smaller than the apparent surface contact, causing an increment in pressure in specific areas. ${ }^{37)}$ As a consequence, the actual contact surface is exposed to a considerable amount of thermal energy. The high temperatures associated with sliding wear are known as "flash temperatures." Conversely, despite the fact that during the sliding (pin-on-disk test), joins between the surfaces continuously form and break, the locations of these joins, 

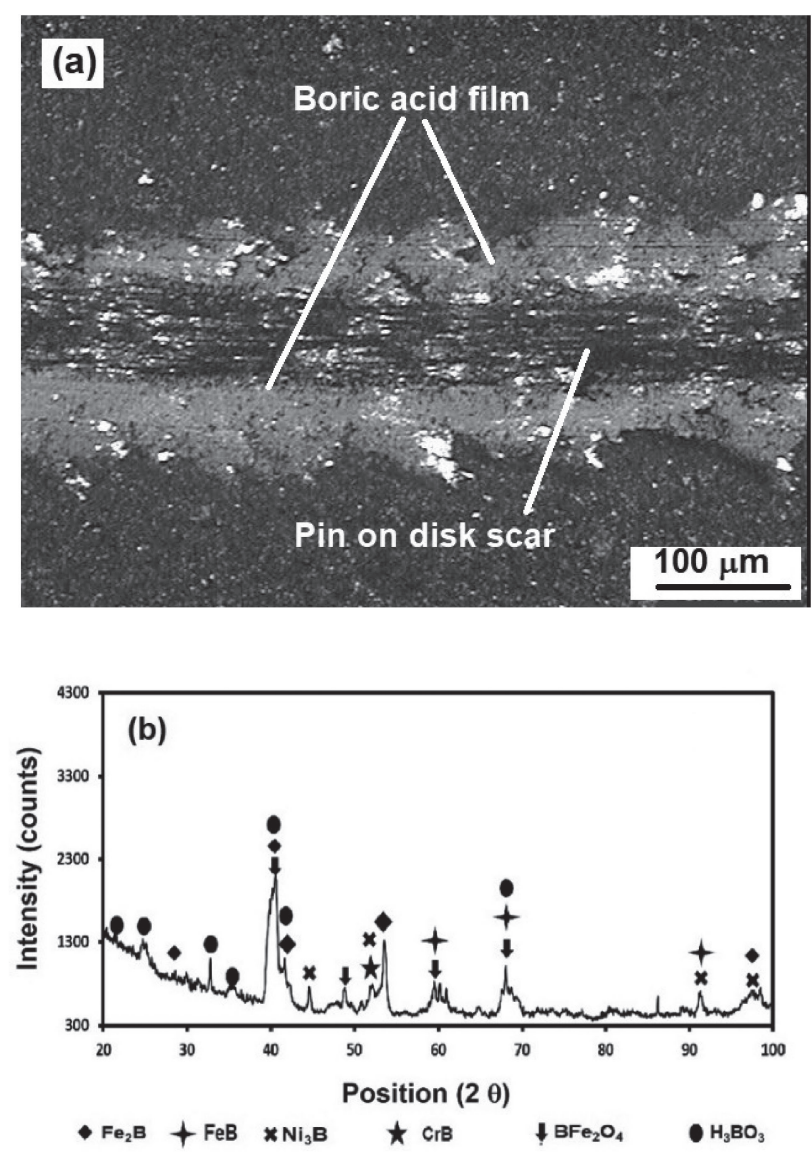

Fig. 11 (a) Wear scar of the pin-on-disk test applied to sample exposed to $900^{\circ} \mathrm{C}$ for $4 \mathrm{~h}$, and (b) XRD pattern after the pin-on-disk test.

and the hot spots on the surfaces, constantly change. The flash temperature reached at any of these hot spots tends to be reasonably constant under constant sliding conditions. The high temperatures reached during the pin-on-disk tests under dry conditions seem to be the cause for the formation of an $\mathrm{H}_{3} \mathrm{BO}_{3}$ film, which acts as a solid lubricant that reduces the $\mathrm{COF}$ of the tribo-pair (boride layers and WC ball). This behavior agrees well with the results reported by Carrera et al., ${ }^{38)}$ showing that boride layers are more resistant to sliding wear under lubricated conditions.

\section{Conclusions}

The aim of this study was to determine the best treatment conditions for enhancing the surface tribological properties of AISI 316L steel. The following conclusions can be made:

(1) The treatment conditions play an important role in obtaining layers with different thickness and hardness.

(2) The hardness values of the layers decreased as a function of their distance from the surface, which indicates that hardness is highly dependent on the boron concentration in the boride layers.

(3) The differences in mass and volume loss during the wear tests can be attributed to the hardness, which is highly dependent on the formation of boride phase $\left(\mathrm{Fe}_{2} \mathrm{~B}\right.$ or $\left.\mathrm{FeB} / \mathrm{Fe}_{2} \mathrm{~B}\right)$.

(4) The layers with the highest hardness values (sample 9) were also the most likely to suffer fracture because of their high brittleness, which agrees well with the results of volume loss, where volume loss was directly proportional to the hardness of the layers.

(5) The COF decreased from 0.8 for non-treated steel to 0.29 for the sample treated for $6 \mathrm{~h}$ at $950^{\circ} \mathrm{C}$ (sample 9). The main reason for this seems to be the naturally occurring boric acid films that appear when the boride layers are exposed to open air. It is clear that a secondary reaction occurs at the surface of the layers and the borided material became more resistant to sliding wear conditions.

\section{Acknowledgments}

This work was supported by research Grant 20180815 of Instituto Politécnico Nacional in Mexico. The authors wish to thank the Center of Nanosciences and Micro-Nano Technologies of the Instituto Politécnico Nacional for their cooperation. Additionally, they would like to thank the Instituto Tecnológico de Estudios Superiores Monterrey in Mexico for its collaboration in the development of this work.

\section{REFERENCES}

1) M. Kulka, D. Mikolajczak, N. Makuch, P. Dziarski and A. Miklaszewski: Surf. Coat. Tech. 291 (2016) 292-313.

2) B. Seral García, T. Castiella Muruzabal, L. Paniagua Royo, J. Segura Mata and E. Seral Íñigo: Revista Española de Cirugía Osteoarticular 31 (1996) 171-176.

3) I. Gurappa: Surf. Coat. Tech. 161 (2002) 70-78.

4) O. Allaoui, N. Bouaouadja and G. Saindernan: Surf. Coat. Tech. 201 (2006) 3475-3482.

5) M. Keddam and S.M. Chentouf: Appl. Surf. Sci. 252 (2005) 393-399.

6) A. Graf von Matuschka: Boronizing, 1st ed., (Carl Hanser, Munich, Germany, 1980).

7) V. Jain and G. Sundararajan: Surf. Coat. Tech. 149 (2002) 21-26.

8) I. Campos, O. Bautista, G. Ramírez, M. Islas, J. De La Parra and L. Zúñiga: Appl. Surf. Sci. 243 (2005) 429-436.

9) W.C. Oliver and G.M. Pharr: J. Mater. Res. 7 (1992) 1564-1583.

10) ASTM G-65-00, "Standard Test Method for Measuring Abrasion Using the Dry Sand/Rubber Wheel Apparatus".

11) K. Holmberg and A. Matthews: Coatings Tribology, 2nd ed., (Elsevier, Amsterdam, 2009).

12) M. Carbucicchio and G. Palombarini: J. Mater. Sci. Lett. 6 (1987) 1147-1149.

13) I. Campos-Silva, M. Ortiz-Domínguez, O. Bravo-Bárcenas, M.A. Doñu-Ruiz, D. Bravo-Bárcenas, C. Tapia-Quintero and M.Y. JiménezReyes: Surf. Coat. Tech. 205 (2010) 403.

14) O. Ozdemir, M.A. Omar, M. Usta, S. Zeytin, C. Bindal and A.H. Ucisik: Vacuum 83 (2008) 175-179.

15) M.A. Béjar and E. Moreno: J. Mater. Process. Technol. 173 (2006) 352-358.

16) T. Balusamy, T.S.N. Sankara Narayanan, K. Ravichandran, I.S. Park and M.H. Lee: Surf. Coat. Tech. 232 (2013) 60-67.

17) Y. Kayali, A. Büyüksagis and Y. Yalçin: Met. Mater. Int. 19 (2013) 1053-1061.

18) Y. Kayali, A. Büyüksagis, I. Günes and Y. Yalçin: Prot. Met. Phys. Chem. Surf. 49 (2013) 348-358.

19) I. Ozbek, B.A. Konduk, C. Bindal and A.H. Ucisik: Vacuum 65 (2002) 521-525.

20) S. Sen, U. Sen and C. Bindal: Surf. Coat. Tech. 191 (2005) 274-285.

21) Y. Kayali: Vacuum 121 (2015) 129-134.

22) K. Genel: Vacuum 80 (2006) 451-457.

23) C.M. Brakman, A.W.J. Gommers and E.J. Mittemeijer: J. Mater. Res. 4 (1989) 1354-1370.

24) G. Palombarini and M. Carbucicchio: J. Mater. Sci. 3 (1984) 791794. 
25) G. Rodríguez-Castro, I. Campos-Silva, E. Chávez-Gutiérrez, J. Martínez-Trinidad, E. Hernández-Sánchez and A. Torres-Hernández: Surf. Coat. Tech. 215 (2013) 291-299.

26) E. Meléndez, I. Campos, E. Rocha and M.A. Barrón: Mater. Sci. Eng., A 234-236 (1997) 900-903.

27) I. Campos-Silva, M. Ortiz-Domínguez, H. Cimenoglu, R. EscobarGalindo, M. Keddam, M. Elías-Espinosa and N. López-Perrusquia: Appl. Surf. Sci. 256 (2009) 3128.

28) J.B. Quinn and G.D. Quinn: J. Mater. Sci. 32 (1997) 4331-4346.

29) G. Rodríguez-Castro, I. Campos-Silva, J. Martínez-Trinidad, U. Figueroa-López, I. Arzate-Vázquez, E. Hernández-Sánchez and J. Hernández-Sánchez: Kovove Mater. 50 (2012) 357-364.

30) E. Hernández-Sánchez, G. Rodríguez-Castro, A. Meneses-Amador, D. Bravo-Bárcenas, I. Arzate-Vázquez, H. Martínez-Gutiérrez, M. Romero-Romo and I. Campos-Silva: Surf. Coat. Tech. 237 (2013) 292 298.

31) M. Tabur, M. Izciler, F. Gul and I. Karacan: Wear 266 (2009) 1106-
1112.

32) C. Martini, G. Palombarini, G. Poli and D. Prandstraller: Wear 256 (2004) 608-613.

33) I. Campos-Silva, M. Flores-Jiménez, G. Rodríguez-Castro, E. Hernández-Sánchez, J. Martínez-Trinidad and R. Tadeo-Rosas: Surf. Coat. Tech. 237 (2013) 429-439.

34) A. Erdemir, C. Bindal, C. Zuiker and E. Savrun: Surf. Coat. Tech. 8687 (1996) 507-510.

35) E. Hernández Sánchez, H. Herrera-Hernández, A. Chino-Ulloa, J.C. Velázquez, R. Velázquez-Mancilla and R. Carrera-Espinoza: Adv. Mater. Sci. Eng. 2015 (2015) 1-9.

36) Z.-B. Hu, H.-J. Li, Q.-G. Fu, H. Xue and G.-L. Sun: New Carbon Mater. 22 (2007) 131-134.

37) J.F. Archard: J. Appl. Phys. 24 (1953) 981-988.

38) R. Carrera-Espinoza, U. Figueroa-López, J. Martínez-Trinidad, I. Campos-Silva, E. Hernández-Sánchez and A. Motallebzadeh: Wear 362-363 (2016) 1-7. 